\title{
Finding the New Concept of Social Justice Farm Income in Indonesia
}

\author{
Lilis Ardini \\ Sekolah Tinggi Ilmu Ekonomi Indonesia (STIESIA) Surabaya, Indonesia
}

http://dx.doi.org/10.18415/ijmmu.v6i5.1097

\begin{abstract}
This research aims to construct the farm income concept by considering the value of justice both social and religious. The research was conducted based on Islamic Paradigm using Kuntowijoyo's Theory of Islamic Prophetic Social in understanding the social reality of sugar cane farmer. This research is a qualitative research method of analyzing Islamic prophetic social theory through the pillars of humanization, liberation, and transcendence. As the results of the sugar cane farmer, the study found spiritual values. The values are honesty, belief, Hablum minallah, and Hablum minannas. They are used in the formulations of justice peasants' profits by incorporating elements of Social Justice Value in to Net Farm Income formulation. This research ultimately proposes the new formulation and contributes to developing sharia agricultural accounting practices for making policies on agricultural accounting standards.
\end{abstract}

JEL Classification Code: D14, D63

Keywords: Farm Income; Social Justice; Islamic Prophetic Social Theory; Prosperity

\section{Introduction}

Money is not the main thing for the life of peasants, because of peasants are fighting for nothing, but the right to plant, land, and family (Widyawati, 2012; Sunyoto, 2011). However, an existence of profit in business activities in the form of money is a means of fulfilling the necessities of life. In addition, money is also a fundamental factor in economic activity (Fisher, 1930). Without money, human is not be able to run the activities of his life. Without the profit (money) humans can suffer, therefore all conditions both space and time will serve as intermediaries to generate profit as well. The concept of satisfaction is a reflection of profit. Money is the main capital of earnings in business activities (Jones \& Belkaouli 2010). This view is firmly embedded in the minds of the capitalists.

Unlike the capitalists, the satisfaction of peasants lies not from money that it is only perceived sensuously (Widyawati, 2012). Peasants also do not place profits in the highest position, because profits are put above everything else. The main capital of the peasants is not a money, but a land and the right to plant it. Profits for peasants must reflect to the value of prosperity and justice that are important milestones and merge in profit. Profit should be able to bring prosperity to the life of the farming family, 
bring prosperity to society, and deliver to justice between man and nature, man with the creator, and man with his neighbor (among peasents) (Qutb 1994). Unfortunately, the relationship between the peasants and the company (in this case state own company) is still shows that it causes some condition about farmers away from the prosperous (Amir et al, 2014, Pakpahan, 2004). These defects can be displayed in various forms, which is the "duping" of farmers in the contracting system (Amir and Mulawarman, 2012). In another sense, the term duplication is shown in the placement of farmers as a company burden.

The life goal of a farmer is to maintain and perfect oneself as a human being (Fukuoka, 2006). But, unfortunately by the glory company the goal is tarnished by the fact of farmers are an economic "burden" for businesses or called by burden metaphors ${ }^{1}$. As anconsequence, the burden metaphor make a farmer as an economic burden that it should be kept as small as possible. Expenses in the context of accounting, defined as a decline in economic value in the form of cash out or reduced assets. Expenses are often regarded as liabilities that it cause impairment in equity. To obtain a high income (I), the reduction of expense (E) on revenue (R) obtained must be minimized. Farmers are one form of expense (expense) from companies that it must be minimized to gain corporate profits and even government companies though (Holyoak, 2014). The position of farmers as an economic burden has implications on condition of farmers. Looking back from history, some peasants who realized the loss of position that it made a rebellion through a peasant radicalization movement led by a called Ratu Adil or Imam Mahdi. Radicalization of farmers in the Dutch colonial era because the problem of land where the soil is the root of the agrarian problem. But, in reality the resistance still makes the farmers do not move from the position of a weak load. Besides that, not different from the Dutch colonial period, even during the Old Order and the New Order the peasants still had land-related conflicts with an existing political system that peasants still in the weak position between economic and political (Musta'in, 2007, Ya 'Kub, 2007, Kuntowijoyo, 2011). Economic justice is created by ethical and moral considerations in profit-seeking activities (Mubyarto 1990). When, the government behaves fairly economically, then the essence of ethics and morality must emerge in the relationship between government and peasants.It is not to depress the peasants as an arbitrary burden. It is this justice that should emerge not to usurp the rights of the peasants who make it weak.

Indonesia was once an Asian tiger by being a rice supplier during the war in Cambodia. In that era, Indonesia did not recognize the import activity of rice from other countries. At that time Indonesia was like a paradise land where anything was available in it. But unfortunately the current phenomenon, almost $80 \%$ of food needs including sugar Indonesia has been dependent on imports, and the price rises uncontrollably. It caused sugar farmers to pile up in vain in the warehouse. In 2014, the total demand for national sugar consumption, both for households and small, medium and large industries reaches 4 million tons, national sugar supply of 2.6 million tons. This means that domestic sugar will be able to meet the consumption and the shortfall of 1.4 million tons will be met from imported sugar. In fact, the import of sugar in 2014 reached 3.5 million tons of raw sugar or 3.3 million tons of refined sugar. Imports of excess sugar cause domestic sugar to accumulate in warehouses due to lower refined sugar prices. This causes a gap in the price of sugar in the market, that is between the price of domestic crystal sugar (IDR $8.300 / \mathrm{kg}$ ) with the price of refined sugar (IDR 7,900.00/ kg) (Kompas, November 10, 2014). The national sugar self-sufficiency program aims to produce 5.7 million tons of sugar by 2014. But the achievement of national sugar production at the end of 2014 is only 2.6 million tons.

Why the government prefers to import sugar instead of glancing at domestic sugar production. Various reasons made some argument that the domestic sugar production is not sufficient national consumption. Because the direction of sugar self-sufficiency policy should be questioned as stated in the road map of increasing a sugar production toward sustainable self-sufficiency of sugar in short term (2004-2009), medium term (2010-2014), and long term (2015-2025) (Widjaja, 2014). According to

\footnotetext{
${ }^{1}$ Metaphors are used to interpret an unspoken reality, but not a series of insoluble puzzles (Shank, 2006)
} 
national consumption needs, failure to this policy makes corporates scapegoat farmers for their inability to supply sugar products. The condition of non-developed governance makes the developed countries in managing to the economic needs of its people, symbolized by massive import activities. If this continues, it will be difficult for the country to improve civilization and continue to cause chaos (Pakpahan, 2004).

Table 1. Annual Sugar Import From 2009-2013

\begin{tabular}{llllll}
\hline Quality of Sugar & \multicolumn{5}{c}{ Import Volume ('000 ton) } \\
\cline { 2 - 6 } & 2009 & 2010 & 2011 & 2012 & 2013 \\
\hline Raw sugar & 2,589 & 2,618 & 2,582 & 3,326 & 3,617 \\
& & & & & \\
White Sugar for Direct Consumption & 13 & 447 & 118 & 61 & - \\
$\begin{array}{l}\text { Refined Sugar for Food and Beverage } \\
\text { Industry }\end{array}$ & 150 & 158 & 60 & 99 & 89.3 \\
\hline
\end{tabular}

Source: Subiyono, 2014

Table 1 illustrates that the development of annual sugar imports from 2009-2013. The volume of raw sugar imports increased annually from 2,589 tons in 2009 to 3,617 tons in 2013. This indicates that sugar raw materials in Indonesia are not sufficient for domestic consumption of sugar. This affects the price of food and beverage products, if refined by sugar domestic production that it can supply the needs of the food and beverage industry. It will reduce a price of food and beverage products in the community.

From the above phenomena, it takes a new concept that makes benefits to the peasant through element of social justice. So, the focus of this research is how to construct a new concept of social justice net farm income. Based on the research background, the purpose of this research is to construct the concept of the social justice farm income. Based on the phenomenon of injustice received by farmers. The results of this study are expected to be useful for the development of sharia agricultural accounting practices as a new guideline for farmers. The results of this study are expected to be used to create policies of agricultural accounting standards by stakeholders.

\section{Literature Review}

History of sugar in the agricultural industry is one of the oldest and most important industries in Indonesia. Sugar is clear evidence that Indonesia has triumphed and is viewed by other parts of the world compared to China and Europe. History records Indonesia as the largest sugar exporter in the mid-18th century, reaching more than 400,000 million tons (Knight 2014; 30). Even sugar is a witness to the history of how Indonesia is processed into the nation of Indonesia today (Tandjung, 2010). The hegemony of sugar has been rooted since the early 16th century when the Dutch landed in Indonesia with the aim of searching for spices, because the value of sugar is considered higher than the spices (Tandjung, 2010). This hegemony continued even to its peak in the mid-18th century when exports reached the highest numbers. But, behind the glory of the nation as the largest sugar exporter who succeeded in defeating the Chinese and competing with Brazil is nothing but the result of a policy of forced cultivation. Cultivation is a form of exploitation and blackmail of the earth (Tandjung, 2010). The forced cultivation that lasted from 1830-1870 greatly afflicted the peasants with a stranglehold policy such as the farmers' rewards determined by the Dutch.The location of the plant was determined by the Dutch, and the landless farmer 
was obliged to work $66 \mathrm{hr} /$ year without any reward (Wahyuni Et al., 2009). Peasant simply can not enjoy the triumph of the high export figures, but the duping without being able to fight.

Post-independence when farmers are no longer controlled by the Company, nor does it make independent farmers evidenced by declining productivity and poor quality of sugarcane. The poor quality of sugar cane is affected by both on farm and off farm activities. On farm activities held on by farmers are farming and cultivation of sugarcane to harvest, while off farm activity is when sugar cane is transported until it is processed into sugar by Sugar Company. In addition, the decrease in productivity can be mirrored by a small yield achievement. The low yield is due to the absence of transparency to the sugarcane farmers in the determination of yield achievement both in the weighing tool calibration process, weighing procedure, and recording of weighing result (Manalu, 2006). The condition of the peasants during post-independence did not improve, so the government tried to prosper them through the policy "Tebu Rakyat Intensifikasi” (Intensification of Sugar Cane).

The Indonesian government through the "Tebu Rakyat Intensifikasi" (Intensification of Sugar Cane) policy is trying to separate the smallholder farmers with sugar factories that more farmers can become kings in their own land, but unfortunately this policy does not go smoothly (Hariadi, 2015; Wahyuni et al, 2009). Because, the Dutch do not inherit the things that are educational, but the planting culture of oppression alone. In the 1970s both peasant and Sugar Company were in transition and on the brink of collapse. The worst condition occurred in 1993-1998, when the local sugar could no longer compete with imported sugar due to the excessive price of sugar. This is because of the zero tariff policy agreed by the government with the IMF through Letter of Intent (memorandum of communication). The consequences of opening taps for free importers, made Indonesia flooded with sugar imports (Widiastuty \& Haryadi 2001). The condition of tariff determination and market price of sugar is the main problem that has caused by farmers to suffer until now. The dilemma determination of market price of sugar is dependent on many influencing factors, including international sugar price, distribution system, and rupiah exchange rate (Jati 2013a; Jati 2013b; Subekti \& Carolina 2011; Susila \& Munadi 2008). High international sugar prices are a result of the high supply of the world's largest sugar exporter in the world such as, India and Brazil, bringing local sugar prices up. Meanwhile, when Indonesia's demand increases and domestic sugar is not sufficient to make Indonesia must import and make world demand rise. This supply and demand process is the core of a market price determination of sugar. Demand for sugar continues to increase as population growth increases. The projection of sugar demand in 2020 is 5.1 million tons, so if domestic sugar production does not change it will increase the opportunity of sugar import in 2020 (Sugiyanto, 2007).

The twisted hegemonic hegemony of Dutch colonial period, post-independence until now shows an irony of welfare perceived sugarcane farmers. Post-independence peasant cannot be freed completely from colonialism and oppression, they are free from the clutch of Dutch company but enter the trap of destructive policy. The position of farmers getting worse and domestic sugar productivity continues to decline, so that the government there is no other option except to import large-scale sugar to meet domestic demand for sugar.It is a real consequence of the polemic determination of the yield and the determination of sugar tariffs are still churning. The calculation of yield as the center of the problem gives consequences on the human nature of peasants as human beings who has the nature of materialistic egoism. When, a sugar cane farmers want to achieve real welfare points, the history of sugar farmers' journeys suggests otherwise. Force cultivation is actually brings misery and misappropriation of human rights can actually bring the highest yield achievement in history. Conversely, a freedom that should bring some peasants in the mental cause chaos and lower the yield. The next question is how can farmers survive in two opposite conditions? Is the highest income a farmer's primary goal to the exclusion of his freedom of soul?. A transformation is important to turns some farmers. Transformations can shift the materialistic mindset of egoism carried out by various parties with their respective interests. A sustainable 
transformation for sustainability and benefits that do not exclude the life-side of farmers affecting the welfare of farmers in the sense of farmers' profits.

\section{Research Method}

Understanding the social phenomenon, self-view and position are central to upgrade a knowledge. This view will lead to human thought expresses assumptions about social reality. According to Kuhn paradigm, aids humans in understanding and searching for the completion of puzzle reality pieces. Paradigm is also interpreted as a sharp perception of viewing the world (world view) led to the legitimacy of knowledge (Kuhn, 2012: 43. Couvalis, 1997: 95, Thoha, 2004: 10). The Islamic paradigm is a new term as an alternative way of looking at understanding social reality that it has not been able to be expressed by the social paradigm. Authentic Islam has a structuring capacity, both as a religion and as a science. The function of Islamic paradigm is basically to understand the reality which is value, norm, and principle of Islam in accordance with Al-Qur'an and Al-Hadist (Kuntowijoyo, 2004: 29; Haque, 1991; Kuran, 1986). The Islamic paradigm undermines the egocentric nature that Islam has the rigid, antialtered, and antiquated Islamic views are not true. Islam is a structure sensitive to the social changes that develop in society. To build the ultimate yardstick of Islamic paradigm is al-Tauhid (Kuntowijoyo, 2004: 50; Choudhury, 2008). The structure of Islamic civilization is so integrated with doctrinal framework (Nasr, 1983). In realizing these authentic ideals, the Islamic paradigm way of thinking will contain the consequences of a fulcrum pointing to the Qur'an, which is a revelation from Allah SWT. It is revelation that distinguishes the Islamic paradigm from the western paradigm on the epistemological side, western social epistemology is based on empirical evidence and the reflection of subjectivity, the Islamic paradigm is not only relying on rational and empirical but also God's revelation (Putra, 2011).

Islam is an open paradigm, Islam is neither East nor West. Islam is the world's chain of civilization, including in science. But, it is very guilty to put religion and culture as a mask for looting in order to maintain the status quo in the world of science. Islam is present as an alternative way of thinking is intuitive and more emphasize the sense teachings of Sufism. Islam is not merely inheriting, but also enrichment by incorporating religious values into the space of science both in substance and form (Kuntowijoyo, 2004). The Islamic paradigm that places reason and revelation is able to understand the social conditions of Islamic society compared to the Western paradigm that puts reason and rationality as the basis of truth-seeking. The Islamic community with uniqueness that the solution to all existing social problems is based on the source of the ultimate truth, the revelation of Allah (Al-Qur'an and Hadith). The perspective and approach can be applied to the Islamic society when everything is based not only on reason but also on revelation. This is the underlying epistemology of Islamic paradigm.

Islamic prophetic Islam by Kuntowijoyo that presents a new concept for transforming social conditions from an Islamic point of view. Various injustices that occur in the social environment is a product of human life and essence as a human on earth. Human kind is produced by the interaction between humans and their environment is depends on the "sense of importance"and the sense of belonging importance arises from the source of cosmic importance (Griffin, 2005). Islam has the form of the relationship between the Creator and His creature, the relationship between fellow beings, the universe and life, between human and theirself, between one generation and another (Qutb , 1994). Human obligations as khalifatul fil ardlh bring human into a form called by microcosmic with the universe as macrocosmic. Microscopic man (small world) because there are all elements of the cosmos such as minerals, plants, animals, and even the divine element. Even man is also considered a reflection of God. God created the whole universe with all His power (Kartanegara, 2005). As He says: 
"Have We not made the earth a resting place?. And the mountains as stakes?. And We created you in pairs. And made your sleep [a means for] rest. And made the night as clothing. And made the day for livelihood. And constructed above you seven strong [heavens]. And made [therein] a burning lamp. And sent down, from the rain clouds, pouring water. That We may bring forth thereby grain and vegetation. And gardens of entwined growth (An Naba': 6-16).

Islamic Social Prophetic will bring the transformation of social conditions between humans and other, in the form of amar ma'ruf as a reflection of humanization, nahi munkar as a reflection of liberal, and tukminubillah as a reflection of transcendence. This perspective will guide this research to interpret and transform social conditions in the life of sugar farmers. The transformation presented by Kuntowijoyo to transform thinking, to reinterpret Islamic values both rationally and empirically. This study uses qualitative research methods that directly look at the behavior of individuals and groups of society naturally. The data comes from informants directly engaged in agricultural activities, especially sugar farming. The paradigm used in this study is the Islamic paradigm present to understand the social reality of sugar farmers in the environment from an Islamic point of view. The Islamic prophetic social perspective by Kuntowijoyo will underlie this research through prophetic Islamic social transformation of humanization, liberation, and transcendence.

\section{Data Analysis Method}

In accordance to the purpose of this study, the concept social justice farm income, this research uses the method analysis of Islamic prophetic perspective through three pillars of Kuntowijoyo thinking. The three pillars (humanization, liberation, trancendence) are intended to express and understand the life of farmers both in their social and spiritual relationships, Humanization is intended for research on various social phenomena and its solution of dehumanization, aggressiveness, and loneliness. (Kuntowijoyo, 2002). The goal of liberation is to libert four things, namely (1) materialistic knowledge system and dominance of structure (eg social and sex class system), (2) social system is change from agrarian to industry, (3) political system is release from authoritarian dictator and neofedalism, the goal of civil society formation, and (4) economic liberation for example liberation of inequality and economic injustice (QS. Al-Hasyir: 59). The three pillars of Islamic prophetic Islam serve as a method of analysis in order to transform social conditions in Islamic societies.

\section{Data Collection Procedure}

Data collection conducted by researchers for 6 months from May 2 to October 28, 2016. Researchers are conducted by observations and in-depth interviews to obtain information about the life of farmers. Observations made include observing the economic and social conditions both in the home environment and farm land. This observation is intended to see and capture the meaning of a phenomenon at that moment by relying on attention, trust, unconscious behavior and so on. In addition to observations and in-depth interviews, researchers also participated in a series of sugar cane activities organized by Sugar Company addressed at Tasikmadu-Karanganyar road, Ngijo, Tasikmadu, Karanganyar regency, Central Java. A series of milling activities is held on 10-12 May 2016. By being a participant and following a series of sugar cane events, researchers can explore the culture, customs, and social and spiritual habits of sugar cane farmers. Such activities and beliefs that directly or indirectly affect the sugar cane business. 


\section{Site and Informant}

This research used sugar cane plantation in Solo, Central Java with informants are including sugar cane farmer who joined in Association of Indonesian Smallholder Farmer (APTRI), directors of National Plantation Enterprise IX and XII (PTPN IX and PTPN XII) Administer of Tasik Madoe and Jatibarang Solo Sugar Plant. Indirectly, PTPN IX also has a share in determining the welfare of farmers through agricultural products. In getting the information thoroughly and objectively the researchers conducted by interviews with several parties related to the farmers' income-earning process. Researchers conducted in-depth interviews for some farmers to get a picture and meaning objectively. So, the phenomenon is expressed objectively felt by some farmers is not just one farmer. In addition for farmers, researchers also interviewed administrative officers Sugar Factory in Tasik Madu. The information obtained from farmers and administrators of Sugar Factory then synchronized to obtain objective and linear consistency and truth. The conditions is happened for farmers and sugar factory in Tasik Madu, then confirmed to the Production Director of PTPN IX in order to obtain holistic information on a phenomenon with various factor considerations both operational and normative policies. From a spiritual perspective, researchers interviewed one of the religious leaders who addressed and provided an explanation for a phenomenon that occurs from the point of view of the Qur'an and Hadith. To obtain information beyond the operation of sugar cane farming, but indirectly affect agricultural activities, researchers conducted interviews on the respected cultures in social environment of sugar cane farmers. Habits and beliefs that exist in the social life of farmers become important as an element it can not be separated from the life of farmers.

\section{Result}

\section{Social Justice Value in on farm Activities}

In on farm activities farmers need income before doing the first activity of land lease and nursery. Farmer's capital may come from the profit of the previous period, the profit from drops and bank loans. The profits from the previous period and from the drops are obviously in the form of money either stored in the bank or at home. For loans from farmers banks have a special way, not only using their own names as borrowers, but also using the names of relatives and their families. Mr. Suwandhi, who has become a farmer for 30 years, acknowledged that the family helped in capital as lend his name. This is not easy considering the bet is the name of borrower, but because of its honesty both other family members. The immediate implication of honesty is trust. The trust has been nurtured for many years through honesty becomes the main capital to manage capital loans worth hundreds of millions because of the land it owns as much as 80 hectare. At least Mr. Suwandhi needed Rp 3.2 Billion for initial capital and activity for one period. About the issue of capital loans in policy at the least disturb the farmers.

The honesty of Mr.Suwandhi and Mr. Warsono in managing the loan funds rely on his family with full trust, as an example Mr. Suwandhi involving his brother in loan guarantee to the Bank, while Pak Warsono involves his wife as a financial manager in farming. As disclosed as follows:

"It all managing by my wife, from signing the document, taking the money, and organizing it for plantation actifity. I trust her $100 \%$ "

By positioning his wife as a co-worker indirectly Mr. Warsono has honored his wife and existence in taking care of the family. Mr. Warsono also welcomed to the wife and to manage the entire agricultural assets. Mr. Warsono and Mr. Suwandhi realized that early honesty should be built from the 
smallest scope of self and family of farmers. After the honesty is formed on the private farmers both for themselves and their families, honesty also needs to be realized on the soil and sugarcane plant. Of course, honesty is not meant literally to say the truth as honesty to the word. But, honesty is defined in the form of deeds that should be done without causing harm. Honesty on the land and plants is how the farmer as king on his land treats the soil and plants properly. Not only take an advantage, but also fulfill his duty in caring and preserving.

\section{Social Justice Value in Off Farm Activities}

Yield is the main and most important thing in the business activity of sugar farmers. The yield was obtained from the sample of drops of sap at the time of sugar cane milling in the Sugar Factory. The yield represents the total production of sugar $(\mathrm{Kg})$ per $100 \mathrm{~kg}$ of sugarcane. Yield 7 means that every 100 $\mathrm{kg}$ of sugarcane will produce $7 \mathrm{~kg}$ of sugar. This implies that the quality of cane holds a major influence in the calculation of yield. Sugar cane with good quality (From this point forward it called by SCF (Sweet, Clean, and Fresh) that contributes high Yield value. SCF is a government policy that it can be adopted by farmers to get a high value of Yield. But, unfortunately not all farmers apply SCF on the sugarcane. Because the calculation of sugarcane yield by SCF and sugarcane is not difference of that not significant.

SCF and Yield are implementation of law causality where the premise of one will lead to the occurrence of another premise. Two premises are the responsibility of two parties who have their respective strengths in sugar business activities. SCF is fully owned by farmers on its on-farm activities and Yield is held by the Sugar Factory. Although the calculation of yield is witnessed by both parties and practice in terms of ability, the Sugar Factory holds a large portion. The consequence is an opportunity to corner one party as a cause when the consequences are not in line with expectations.

"...I think there is unfairness on determining yield between sugar SCF and not SCF, it should be different, isn't it?. So the other peasent can learn from it. And also there is no transparency the value yield of Sugar Factory it self. So we don't even know that" Warsono, $4^{\text {th }}$ August 2016

Farmers judge that Sugar Factory not apply the principles of fairness and transparency when performing the calculation of yield. According to Mr. Warsono is a different treatment between farmers who apply SBM and farmers who do not apply SBM to sugarcane. In addition, transparent principle is not applied by Sugar Factory on the calculation of sugar cane yield owned by Sugar Factory. No announcement of the yield of sugar cane in Sugar Factory (in this case Sugar Factory has its own sugarcane) and Yield is figures to make farmers less trust in the implementation of calculation of yield made by Sugar Factory. Besides other farmers also assume the presence of farmers at the time calculation for yield has no significance influence.

Various phenomena above is the view of farmers that Sugar Factory with various dimensions is a factor causing the decline in the value of Yield. On the other hand Sugar Factory will certainly see otherwise, based on the logic of thinking that farmer is the main determinant of.

"So that's all we have to look thoroughly, can not piece a piece. When the milling season arrives no one can predict that it rains continuously ... the cane has its vegetative instinct to grow on the condition. This means that if not immediately milled it will grow the seeds 
... on the other hand farmers also do not want to fair in the process of cutting. Garbage comes in. So they should not be surprised when the yield is low because the waste also come as a ballast ". Mr. Agung Administrator of Sugar Factory Tasik Madoe.

If starting from the definition of yield, it is logical that the low yield resulting from the accumulation of cane amounts as the denominator. It cannot contribute sugar when it is squeezed. Logically, if you want to produce a high yield then cane as the denominator in the calculation of the yield must be sugarcane that are contains (not a mixture of waste). More detail is explained by one of the administrative directors of PTPN (plantation state own company) IX when the researcher confirmed the condition of Mr. Warsono.

"The accusation that the Sugar Factory administrators set the yield, it happened because of ejected from the farmer who sat as a victim ... in this case Mr. Warsono is a victim ... assuming Mr. Warsono is right .. but is it really true ?. Because Mr. Warsono's preconditions here as innocentman ...When talking about what happens in the field, the farmer is honest, but many do not ... and we can minimize dishonesty through what ?. "

The director in the administration of PTPN IX above are not spelled out by the defense of protests peasants, but the mistrust of relationship. In this case, the condition of the marginalized by farmers because of the yield disputes. The view is created based on the technical implementation at the time of milling and sample determination for the calculation of Yield. The sample determination policy falls on the first drops of sap for reasons that dishonesty of some farmers who are generalized to all farmers. According to PTPN IX, a stabilize the condition of farmers and sugar factory in minimizing the dishonesty. Distrust between farmers and sugar factory emerged because of the principle of honesty in running business activities. Honesty is cannot be witnessed physically, but one form of belief in the existence of God the Almighty is applying the principle of honesty wherever and whenever. A Muslim who runs the first pillars of faith that is faith in God should believe that God is a witness to all the deeds that people do. In the Qur'an Allah says:

"O you who have believed, be persistently standing firm for Allah, witnesses in justice, and do not let the hatred of a people prevent you from being just. Be just; that is nearer to righteousness. And fear Allah ; indeed, Allah is Acquainted with what you do". (QS. AlMaidah :28)

The value of honesty will produce trust as a consequence. Muslim beliefs reflected in the peaceful exercise of faith. Faith in God, faith in the Apostles, the faith in God's book, the angel of faith, faith in the Hour be established, and faith in the destiny and decree of Allah. Reflections of Faith in God is the only one to be honest. Believe that God will give you the results of the efforts made His servant. Allah knows what is best for His creatures, and that the justice of God has the nature of Al-'Adl. Value trust must be instilled not only horizontally to one another (farmers to Sugar Factory) but also the transcendental to God. Trust in humans can avoid one of the limitations of others, which can lead to a reduction of the rights and freedoms of a person. Belief in God (in His existence and His Providence) is the realization of the first pillars of faith that can make a person always behaved honestly and fairly. 


\section{The Concept of Social Justice Farm Income: The Process of Social Transformation}

Based on the value of social justice will bring peasants to freedom both economically and spiritually. Economically, peasants are free from the trappings of materialist passion, so as to shake off the thirst for material that is never ending. Spiritually, the peasants will be free from the potential of tyranny and blend with their Lord to give birth to the God-ness nature. In the determination of social justice farm income, the transformation is based on the concept of social justice applied to every businessman who wants to move forward in the direction of transformation that goes beyond modernization. So, there is no room for materialism and logocentrism to dominate the human soul. The concept of social justice was born to answer the reality of injustice that occurred in the calculation of farmers' profits. As the concept of Shariah Enterprise Theory is present to answer the reality of a concept for Enterprise Theory by changing the orientation of profit toward the orientation of zakat through the "Metafora zakat" and "metafora amanah" (Triyuwono, 2012). The concept of social justice invites individuals to be oriented towards Tawheed as the ultimate goal as well as the transformation process. The concept of social justice in application to the calculation of the profit of farmers not only affects the process of acquisition merely but only on the distribution of the profit. In a process of earning profit, the concept of social justice focuses on the process of planting and maintaining sugar cane as the main product. The value of justice applied to the profit-generating process will reduce the frauds in the farmers' profit calculation process. In the distribution process, the concept of social justice focuses on the process of determining and distributing profits. By entering the values of fairness in the process of determination and distribution of profits will reduce the existence of usury that harm one party. The concept of social justice in the determination of farmers' profits will give rise to a just social reality and bring about social welfare. By applying the concept of Social Justice is not impossible the ideals of the predecessor in achieving social justice for all levels of society.

The calculation of the profit of the social justice farmer described in a qualitative way is as follows:

$$
\text { Social Justice Farm Income }=(\mathrm{TO}-\mathrm{I}) \mathrm{x} \text { Social Justice Value }
$$

1. TO, refer to Total Output or Total Gross Output, it is gross profit earned from sugar cane sales

2. I, refer to Input, it is the costs incurred during the agricultural process

3. Social Justice Value is, the values of justice emerging during the agricultural process in order to achieve the farmer's justice profit. These values include the value of honesty, trust value, and hablum minannas

Honesty born in the process of sugar cane farming will ultimately lead to the maximization of value and the rate of yield in sugar cane. Sugarcane with good yield potential in the garden should be maintained during post-harvest or processing. This is done by cutting sugar cane in a state of cooking and transported as soon as possible to be processed in Sugar Factory so that the possibility of losing sugar is minimal.

$$
\text { Social Justice Farm Income }=(\mathrm{TO}-\mathrm{I}) \mathrm{x} \text { Social Justice Value }
$$

When social justice value is carried out through (assumed) 100\%, then:

$$
\text { Social Justice Farm Income = }(\mathrm{TO}-\mathrm{I}) \text { x 100\% }
$$

This means are the profit earned is the profit of farmers with social justice perfect or intact (spiritually and economically) with the assumption of total output and input calculation in accordance with the calculation. Consequently, if farmers do not apply the value of social justice at all during the process of agriculture (metaphorized) $0 \%-99 \%$, then the calculation of social profit earnings farmers who get not intact. Honesty of $0 \%$ mathematically will result in social profit of farmers equal to 0 as well. 
Number 0 is not merely means IDR 0 , - (economically) but interpreted spiritually that there is no blessing in the profits earned farmers. Or in other words does not reflect the earnings of farmers with social justice. Number 0 in economic meaning IDR 0, - may occur when the economic calculation of total gross output is greater than or equal to its input $(\mathrm{TO} \geq \mathrm{I}$ ). The above explanation can be described with the following table:

Table 2 Social Justice Farm Income

\begin{tabular}{llll}
\hline Social Justice Value & economy & Spiritual & Result \\
\hline $0 \%-99 \%$ & IDR x & IDR 0 & $\begin{array}{l}\text { Greedy } \\
\text { Egosentris }\end{array}$ \\
& & & Blessing \\
$100 \%$ & IDR x & IDR x & Benefits \\
\hline
\end{tabular}

The table above shows that the socially just farmer's profit is born from the value of social justice. When farmers in their farming activities do not apply social justice (range 0 - 99\%) because farmers are still enveloped by lust, greedy, and egocentric which will result in injustice in just earnings. Meanwhile, when farmers in their agricultural activities reflect social justice $(100 \%)$ because the farmers realize that the farmers' profession to welfare together so that the spiritual will aim to bless the people.

\section{Conclusion}

This study answers the question that how the farmers' social profit construction in socially time. The socially just farmer's profit is needed to eliminate the injustice that is present and cause the farmer to become the subject of hegemony. The concept of profit is one way and the beginning for the process of Islamic social transformation. Islamic social transformation by Kuntowijoyo thought able to answer the need of social and spiritual values to bring individuals to do hijrah and to a better condition. Based on amar ma'ruf, nahi munkar, and tukimuna billah will lead to human behavior to pay more attention to others, nature, and also God, including the business of sugar cane farming. Sugarcane farmers in their agricultural business activities must reflect to Islamic prophetic values based on humanization, liberation and transcendence considerations. From these considerations will give birth to Islamic social justice values of honesty, trust, and hablum minannas. The first value of justice is honesty, honesty is the consciousness of peasants that nature is one of the human responsibility to guard it. As khalifatullah fil Ardl man representing God in this earth. In the process of raising sugar cane crops, farmers must reflect to the honesty from the nursery process, maintenance, fertilization, and the process of hauling.. The cutting process by burning to achieve time and energy efficiency. But, the behavior will take to another problem that is produced by sugarcane, and not SCF, and produce low yield value. The second value of justice that belief in 3 meaning that is belief to fellow farmers in representing auction forum, belief to sugar factory in milling process, and highest trust to Allah as omnister and omnipotent. So, without the human value trust and it will be filled with negative thoughts actually cover the cleanliness of the heart and find the object to blame. Without the trust of farmers and sugar factory will blame each other on the activities affecting the calculation of yield. The third value of justice is hablum minannas, it cannot be denied as homo socius farmers will enter into the social system created by a group of people. In the agricultural business process farmers need cooperation from various parties such as the surrounding community as a provider of human 
resources, from fellow farmers as representatives who are members of an association. In addition, farmers also establish hablum minannas with sugar factory as its partners to get the meaning of real partners.

\section{Research Implication}

This research has theoretical implications, practices and policies. The results of this study have theoretical implications in giving birth to a new concept in the science of accounting, especially agricultural accounting. As practical implications, the concept of social justice farm income as a whole encourage the perpetrators of agricultural business activities to run a agricultural business based on the concept of social justice by the unification of justice values in every business activity. These values of justice can be planted not only in farmers, but also in Sugar factory as partners. This new concept also reduces unfair business practices and emphasizes only certain groups. Not only in the context of merely accounting scholarship, but also this concept will place a man on the purpose of his religious existence as a servant of God.

As a policy implications, the construction concept of social justice farm income will be one of the considerations for stakeholders in determining the future of farmers as one of the agricultural actors. The farmer is a State asset that is indispensable in creating food self-sufficiency in order to achieve food security as predicted by its predecessor. The results of this study show that various phenomena and solutions in overcoming and it can create a government thinking to formulate policies related to agricultural accounting such as auction policy, milling, and other realities. Furthermore, it will create policies that can build a system and implements the value of justice as one of some elements and it cannot be left behind, such as the banking capital lending system. So, it will create a system in the agricultural business actors from National Plantation Enterprise (PTPN), Sugar Company, Bank, Cooperative, and Farmers will apply the concept of social justice in accordance with the conditions of each.

\section{Suggestion}

This research was conducted on the life of sugar cane farmers who joined and followed by the grinding program Sugar Company Tasik Madu in Solo, Central Java. One limitation of this research is just focuses on sugar cane farmers. But, not the construction of sugar cane farming profits required by the cooperation of various business actors incorporated therein such as Sugar Company, Bank, and National Plantation Enterprise (PTPN). Further studies to determine the construction for the concept of divine earnings and the Divine from the glasses of other subjects as mentioned above are necessary in order to create a system that carries out divine justice in the process of comprehensive profit retrieval. Because the injustices received by farmers arise from other subjects who may not be directly related to the farmers. Leaving in the formation of some concept for social justice farm income on another subject will result in a system based on social justice. 


\section{Reference}

Amir, V, Mulawarman, A D., Kamayanti, A, Irianto, G. (2014). Gugurnya Petani Rakyat: Episode Perang Laba Pertanian Nasional. Ub Press. Malang.

Amir,V dan Mulawarman, AD. (2012). Menggugat Politik Ekonomi Pertanian: Petani Vs Korporasi. Seminar Nasional dan Call for Paper UPN Jogjakarta.

Couvalis, G. (1997). The Philosophy of Science: Science and Objectivity. SAGE Publication. London.

Fisher, I., (1930). The Theory of Interest as Determined by Impatience to Spend Income and Opportunity to Invest it, The Macmillan Company.

Hardiman, B., (2009). Demokrasi Deliberatif Menimbang 'Negara Hukum' dan 'Ruang Publik' dalam Teori Diskursus Jurgen Habermas. Penerbit Kanisius. Yogyakarta.

Hariadi, B., (2015). Revitalisasi Pabrik Gula Milik Negara Dalam Jeratan Decoupling. Jurnal Akuntanssi Multiparadigmaa, 6(2), pp.304-315.

Haque, Z., (1991). Islamization of Economy in Pakistan (1977-88): An Essay on the Relationship between Religion and Economics. The Pakistan Development Review, 30(4), pp.1105-1118.

Holyoak, J. L. (2014). Water Sharing Risk in Agriculture: Perception Of Farm Dam Management Accountability In Australia. Journal of Agriculture Water Management 145 (2014)123-133.

IASB. (2011). International Accounting Standards IAS 41” Agriculture.

Jati, K., (2013a). Sugar Commodity Price Analysis : Examining Sugar Producer Countries. International Journal of Trade, Economics, and Finance, 4(5), pp.288-295.

Jati, K., (2013b). Sugar Price Analysis in Indonesia. International Journal of Social Science and Humanity, 3(4), pp.369-374.

Jones, S. \& Belkaouli, A.R., (2010). Financial Accounting Theory 3rd edition, Cengage Learning Australia.

Karim, W.J., (2010). The Economic Crisis, Capitalism and Islam: The Making of a New Economic Order? Globalizations, 7(June), pp.105-125.

Kartanegara, M. (2005). Menembus Batas Waktu Panorama Filsafat Islam. Mizan Pustaka. Bandung.

Kuhn, T. (2012). The Structure of Scientific Revolutions. Peran Paradigmaa Dalam Revolusi Sains. PT Remaja Rosdakarya. Bandung.

Knight, G.R., (2014). Sugar, Steam and Steel: The Industrial Project in Colonial Jawa, 1830-1885, Australia: University of Adelaide Press.

Kompas. (2014). Gula Petani Menumpuk di Gudang. Pertanian. Kamis 13 November. Jakarta.

Kuntowijoyo. (2004). Islam Sebagai Ilmu: Epistemologi, Metodologi dan Etika. Mizan Media Utama. Bandung. 
Kuntowijoyo, (2008), Paradigmaa Islam Interpretsi Aksi. Mizan Publika, Bandung.

Kuran, T., (1986). The Economic System in Contemporary Islamic Thought: Interpretation and Assessment. International Journal of Middle East Studies, 18(2), pp.135-164.

Mubyarto. (1990). Ekonomi Pancasila: Gagasan Dan Kemungkinan. Lembaga Penelitian, Pendidikan, Dan Penerangan Ekonomi Dan Sosial. Yogyakarta.

Mulkhan, A. M. (2015). Intisari Ajaran Syekh Siti Jenar Wihdatul Wujud dalam Pemikiran Islam-Jawa. Penerbit Narasi. Yogyakarta.

Nasr, S.H. (1983). Islam dan Nestapa Manusia Modern. Penerbit Pustaka. Bandung.

Pakpahan, A. (2012b). Pembangunan Sebagai Pemerdekaan Pemikiran untuk Membalik Arus Sejarah Pembangunan Nasional. Gapperindo Jakarta.

Putra, A,. (2011). Paradigmaa Profetik, Mungkinkah? Perlukah?. Sarasehan Profetik 2011. Universitas Gajah Mada. Yogyakarta.

Quthb, S. (1994). Keadilan Sosial Dalam Islam. Penerbit Pustaka. Bandung.

Shank, G. (2006). Qualitative Research A Personal Skill Approach Second Edition. Pearson Education Inc, New Jersey.

Wilson, Rodney., (2006). Islam and Bussiness. Thunderbird International Business Review, 48(1), pp.109-123.

Stone.J.A. (2012). The Accountant And Farm Management Advice. University Of New England. Australian Journal Of Agricultural Economics. Volume 7, Issue 2.

Subekti, N.A. \& Carolina, R.A., (2011). Pengaruh Kebijakan Tarif Impor Gula Terhadap Integrasi Pasar Gula DomestiK dan Dunia. Buletin Ilmiah Litbang Perdagangan, 5(1), pp.84-104.

Subiyono, (2014). Sumbangan pemikiran Menggapai Kejayaan Industri Gula Nasional. PTPN X. Surabaya.

Sugiyanto, C., (2007). Permintaan Gula Di Indonesia *. Jurnal Ekonomi Pembangunan, 8(2), pp.113127.

Sumaryono, E. (1999). Dasar-Dasar Logika. Kanisius. Yogyakarta.

Susila, W.R. \& Munadi, E., (2008). Analisis Keterkaitan Harga Gula Eceran, Sistem Distribusi dan Laju Inflasi. Informatika Pertanian, 17(1), pp.1085-1103.

Thoha, M. (2004). Paradigmaa Baru Ilmu Pengetahuan Sosial dan Humaniora. Mizan Publika. Jakarta.

Triyuwono, I. (2012). Akuntansi Syari'ah Perspektif, Metodologi, Dan Teori. Grafindo Persada. Jakarta.

Wahyuni, S., Supriyati \& Sinuraya, J.., (2009). Industri Dan Perdagangan Gula Di Indonesia: Pelajjaran Dari Kebijakan Zaman Penjajahan - Sekarang. Forum Penelitian Agro Ekonomi, 27(2), pp.133-149. 
Wibowo, Wasino, dan Setyowati. (2012). Kearifan Lokal Dalam Menjaga Lingkungan Hidup (Studi Kasus Masyarakat di Desa Colo Kecamatan Dawe Kabupaten Kudus). Jurnal of Education Sosial Studies Vol.1 No.1 2012 pp. 24-30. Semarang.

Widiastuty, L.K. \& Haryadi, B., (2001). Analisa Pemberlakuan Tarif Gula di Indonesia. Jurnal Manajemen \& Kewirausahaan, 3(1), pp.34-47.

Widjaja, A. (2014). Kebijakan Setengah Hati Evaluasi Pergulaan Indonesia.mizan Publika. Jakarta.

Widyawati, W. 2012. Etika Jawa Menggali Kebijaksanaan dan Keutamaan Demi Ketentraman Hidup lahir Batin. Pura Pustaka Yogyakarta. Yogyakarta.

Ya'kub, A. (2007). Konflik Agraria Tinjauan Umum Kasus Agraria di Indonesia. Federasi Serikat Petani Indonesia (FSPI). Jakarta.

\section{Copyrights}

Copyright for this article is retained by the author(s), with first publication rights granted to the journal.

This is an open-access article distributed under the terms and conditions of the Creative Commons Attribution license (http://creativecommons.org/licenses/by/4.0/). 